\title{
Cube Assessment Framework for B2C Websites Applied in a Longitudinal Study in the Luxury Fashion Industry
}

\section{Rina Hansen ${ }^{1}$ and Niels Bjørn-Andersen ${ }^{2}$}

Copenhagen Business School, Department of IT Management, Copenhagen, Denmark, ${ }^{1} \mathrm{rh} . \mathrm{itm} @ \mathrm{cbs} . \mathrm{dk}$, 2nba.itm@cbs.dk

Received 29 March 2012; received in revised form 3 December 2012; accepted 9 January 2013

\section{Abstract}

A literature review of existing assessment frameworks for $\mathrm{B} 2 \mathrm{C}$ websites over more than ten years reveals that they are all built bottom-up through an essentially empirical approach of recording functionalities/features without any theoretical construct to guide the design of the framework. In an attempt to develop a theoretically consistent framework, this paper first identifies all relevant assessment categories and sub-categories for B2C websites in the luxury fashion industry. In total, eight categories and 29 sub-categories (actual assessment criteria) are identified. This framework is then applied to 15 luxury fashion brands in a longitudinal study in the years of 2006, 2008, 2010 and 2012. These four surveys document the substantial changes in website functionalities/features over the period, especially relating to how Web 2.0 and social media are diffused and adopted in the luxury fashion industry. A careful analysis of the eight categories and sub-categories reveals that the B2C website design can be characterized (and indeed defined) by virtue of three strategic choices regarding website design. The three strategic choices together with the eight categories form the basis for a theory for website design, which we name the CUBE model. We believe this model to be relevant beyond the luxury/fashion industry.

Keywords: Website, Assessment, CUBE, Luxury, Fashion, Web 2.0, E-commerce, Branding, Social media, Longitudinal 


\section{Introduction}

Since the appearance of Internet websites in the mid 90's, this channel has become a major outlet for e-commerce as well as branding/marketing to consumers. In the U.S, Internet sales accounted for $5 \%$ on an adjusted basis or $\$ 54.8$ billion in Q2 of 2012, an increase of 15.3\% over Q2 of 2011 [46]. In most e-commerce developed countries (such as the Nordic countries) the turnover in Internet purchases now exceeds 10\% [17]. The Internet is also becoming the largest medium in terms of spending on advertising and is taking center stage in marketing and sales functions. Thus, the layout, design and functionality of Internet websites are becoming more and more critical to the attainment of company branding and sales objectives.

Apparel and accessories accounts for one of the largest categories sold online, enjoying double digit growth rates year after year [17], [46]. Still, established fashion brands struggle to rethink their traditional sales and marketing strategy to include the digital channels in order to make the brands fit for the future. They are hesitant due to the dilemma of maintaining exclusivity and brand control. The brands fear implementing interactive elements on their websites for customers and fans to interact or customize products will make them lose control of their brand. This attitude is slowly changing as the majority of fashion brands are realizing the importance of Internet presence. Especially forced by the recent declining sales in physical stores due to the economic downturn, fashion brands have turned their attention to online, where e-commerce still promises double-digit growth [33].

Interacting and shopping across channels are also exactly what customers expect from brands. Previous research in the context of online fashion shows that customers want a website experience that is engaging, memorable and interactive; in other words, they prefer a website that can offer social interaction, two-way communication and a personalized relationship with the brand [35], [44]-[45]. Moreover, industry reports from McKinsey and Economist business surveys point out that the interactive and collaborative aspects are seen as opportunities for increasing a company's revenue and/or margins [6]-[7], [10].

However, selling and branding fashion brands online require a different set of tools and strategies than do selling and branding commodity products offline. Fashion brands combine emotion, image and perception. Hence, the challenge is how to convey these characteristics of intangibility, tangibility, and multi-sensory experiences online using Internet technologies [6]-[7], [10], [24], [44]-[45].

With the help of Web 2.0 technologies, luxury fashion brands can create an immersing and innovative store environment online [33]. For instance, in the related industry of jewelry, Cartier (www.cartier.com) has created a visual tour of its brick-and-mortar store, through which one can navigate online. It is entertaining, keeps the visitor involved and creates emotional hooks through the use of videos and engagement. According to Jennings [22], an ebusiness that does not provide such an experience will not thrive. However, to-date, there is no luxury fashion brand website (including community using social media) which allows visitors to navigate through the store, see the current collection on the shelves and drag and drop them into the basket, all the while being advised by a real time eshopping assistant. Furthermore, there are no luxury fashion brands that actively use crowdsourcing on their website or on social media sites to its fullest extent.

It is the purpose of this paper to assess the extent to which the luxury fashion industry has availed itself of these opportunities through a longitudinal study of 15 of the most well-known brands over the years 2006, 2008, 2010 and 2012. Based on this, we set out to develop a theoretically consistent framework for strategic choices regarding website design. (By framework we mean a coherent set of interrelated concepts with definitions of each concept and specific scales of characteristics for measurements.) Given the important developments, especially with Web 2.0 technologies, our framework has been developed especially to take into account interactive and social media.

The three research questions of this paper are:

1. What are the relevant categories and sub-categories for an assessment of luxury fashion websites relevant for characterizing the adoption and diffusion of website functionalities/features, especially taking into account the most recent phenomenon of Web 2.0 and social media?

2. What has been the adoption and diffusion of these functionalities/features in the luxury fashion industry over the last six years?

3. What would be the characteristics of a theoretically consistent framework based on strategic choices for the design of websites based on the categories?

In order to address the first question, we conducted a literature survey of the different assessment frameworks for B2C websites. After careful deliberation, we adopted the $8 \mathrm{C}$ framework by Yang et al. [48] as a starting point, and developed a detailed set of measurements (sub-categories). We ended with eight categories and 29 sub-categories or specific measurements to be empirically tested. 
Regarding the second question, we applied the framework in one of the most challenging industries, namely, the luxury fashion industry. Luxury is not a product, object or service; neither is it a concept or a lifestyle. It is an identity, a philosophy and a culture. Its function is deeply rooted in the social classes of past civilizations when royals, nobles and aristocrats used ostentatious consumption to stamp their superiority, maintaining their distance from the lesser privileged [33]. Luxury offers exclusivity, quality, image and status, and this combination makes luxury desirable for reasons other than function [18].

From a product perspective, luxury goods are frequently defined in terms of their excellent quality, premium price, distinctiveness, exclusivity and craftsmanship [18]. The luxury purchase is often associated with an emotional experience in retail theaters, i.e., opulent flagship stores in the most expensive streets of the world guarded by doormen and served by beautiful sales advisors. Since the core of luxury is control of the brand and perfection of its products, it seems like a distant activity to involve consumers in two-way interaction and in co-creating products. Accordingly, if the framework would work in this specific industry case, there would be a high probability that it would also work in other industries.

The third research question is theorizing from our findings. The theoretical contribution is the insight that each of the eight categories can be characterized by three strategic binary choices, thus leading to the development of the CUBE framework. Since we have three binary strategic choices, the combination is $2^{3}$ creating a cube with eight cells, which we show matches the $8 \mathrm{C}$ framework. In other words, in this section we are matching the top-down approach starting with the three strategic choices with the bottom-up empirically approach coming from the $8 \mathrm{C}$ list. This cube framework is empirically tested through a longitudinal study over four surveys of 15 luxury band websites carried out in the autumn of the years 2006, 2008, 2010 and 2012. Given that the list of categories and subcategories was relevant over this period one might say that the CUBE framework has stood the test of time.

The paper is organized into six sections including the introduction. Next follows a literature review setting the stage for our choice of categories for the evaluation of B2C websites, especially pertaining to luxury fashion brands, and the eight $\mathrm{C}$-categories are introduced. The third section describes our methodology for website evaluation, and provides the method of conducting the four surveys. The next section reports on the B2C web-site assessment results of how luxury brand providers have utilized this channel for its business processes vis-à-vis potential customers, current customers and fans. For each category we define the category, analyze developments over the four surveys and highlight interesting observations, especially regarding the use of Web 2.0 features. The fifth section discusses how the longitudinal comparison is systematically carried out, along with the extent to which luxury fashion brands have matured during the period and utilized the possibilities, especially in using social media. The sixth section takes its starting point in the three strategic choices for design of $\mathrm{B} 2 \mathrm{C}$ websites, and continues to provide the theoretical contribution in the form of our CUBE assessment framework. The paper ends with conclusions, implications and future research opportunities.

\section{Assessment of Websites in the Literature}

There is a fairly extensive tradition for studying websites. Since the late 90 s, researchers and website developers have developed different types of frameworks for assessing, comparing and designing websites. The 1999 LSE/Novell framework evaluated the web-presence of the top 10 largest companies [29], concluding that most of the websites were limited to provision of information, and only a few had capabilities for e-commerce. The more comprehensive CEH-framework (see Elliot et al. 2000, [16]) for assessment of websites identified six categories (company information, product/service information, transaction processing, customer services, ease of use and innovation), where each identified five levels of excellence that would be useful for scoring the status of a particular website.

In a comprehensive review of website assessment frameworks between 1995 and 2006, Chiou et al. [13] identified no less than 83 articles, and classified them as to which approach they had applied: an IS, a marketing or a combined approach. They found that while a combined approach in the period $1995-2001$ was only applied in $27 \%$ of the studies, this figure increased to $55 \%$ in the period $2001-2006$. We suspect that this figure grew because in using a combined approach, it was necessary to integrate the vendor (brand) as well as the consumer perspective.

In another attempt at providing a consolidated view of categories studied in web-assessment studies, Park and Gretzel [37] classified all categories into 12 so-called unifying categories listed in order of frequency of use in the studies investigated by Chiou et al. [13]: ease-of-use, responsiveness, fulfillment, security/privacy, personalization, visual appearance, information quality, trust, interactivity, advertising/persuasion, playfulness and technology integration. This is a very useful overview of the abstract concepts applied in assessment of websites, and we have built on these to identify assessment categories and sub-categories.

In general, assessment of websites in the last decade has been carried out from three different perspectives:

- $\quad$ the user (consumer) perspective, where the underlying premise of these studies is that the performance of the website is measured by how satisfied the users are and consequently how willing they would be to revisit the site (see, for example, Muylle et al., 2004 [32]; Zviran et al., 2006 [49]), 
- $\quad$ the developer (developer) perspective, which reveals which graphical and technical features are imperative for websites (see, for example, Auger, 2005 [3]; Jennings, 2000 [22]) and

- the owner (brand) perspective, which helps to pinpoint areas within the business where the website is creating value for the company (see, for example, Ghandour et al, 2011[20]; Huizingh et al., 2007 [21]; Quaddus and Achjari, 2005 [41]).

While the user and developer perspectives are well represented in the literature, there is little research on developing websites and online business strategies from a brand owner's perspective [20], such as we are proposing to do here. The reason for the focus on owners is that we are interested in the strategic choices made (or to be made), when a brand owner decides on its Internet/Web-site strategy. This can be either by design (because it is something actively pursued), default or as an emergent strategy [30], that is, something which has come about as a result of serendipity or a series of incremental changes. Accordingly, we take a clear brand owner's perspective, analyzing the potential advantages involved in particular strategic choices.

There are a limited number of empirical studies of luxury brand websites. Siddiqui et al. [45] evaluated 14 fashion websites and conducted two in-depth interviews with personnel in each store. Their research emphasizes that consumers express a need for social interaction, two-way interaction mode and a greater level of interactivity online, all of which are not met by luxury brands. They found from these consumer interviews and focus groups that visitors are disappointed by the low level of interactivity presented by the websites, concluding that "it is evident that consumer's experience and expectations far exceed the retailer's ability to understand and satisfy consumer needs online" (p4). Siddiqui et al. [45] concluded that there is a lack of human and social interaction online and that consumer expectations in products and services online are not met by fashion websites.

Riley and Lacroix [35] evaluated 26 fashion websites and conducted five in-depth interviews. Their research argued that Internet presence is both an opportunity and a threat, but they recognized that consumers demand the opportunity to be involved in a relationship with a brand. Accordingly, they recommended that the degree of control over the brand may need relaxing so that non-moderated communities could be built within the brand's website. "This would enable the companies to engage in a more unfiltered dialogue with their public" (p2). Riley and Lacroix [35] concluded that websites' interactivity features are crucial to Internet marketing success, but are less likely to be used as a tool for commerce, the reason being that the Internet does not provide the pleasure and social experience of entering the physical store.

Seringhaus [44] evaluated 190 luxury brand websites; of which 45 were fashion and leather goods brands. The author questions the feasibility of recreating the brick-and-mortar store online, and purports that luxury marketers must find a way to use the web to maintain a sense of drama. "They should innovate not recreate store atmospherics online, but create a seamless integration of on and offline into a complementary experience" (p16). Riley and Lacroix [35] and Seringhaus [44] concluded that differentiation from competitors online are more difficult, as critical points of distinction, such as showrooms, store displays, personal selling, service, and the experiential touch and feel, are currently lacking.

In summary, the three studies conducted by Siddiqui et al. [45], Riley and Lacroix [35], and Seringhaus [44] show that luxury brands generally do not have interactive, entertaining or engaging websites, and therefore do not meet consumer expectations. A reason given by Kapferer and Bastien [24] is that luxury fashion brands are facing the Internet dilemma: "A luxury product can communicate via the Internet, but should not be sold there" (p.207). Their viewpoint is that an Internet strategy is indispensable for luxury brands as a means of communication, advertising and as an experiential tool; however, if a luxury product is placed for sale on the Internet, it is no longer a luxury product.

Summing up the deliberations thus far, we need a robust well researched framework, which will be useful for the assessment of B2C websites within the luxury fashion industry, and we believe that the Rayport and Jaworski's [42] 7C framework is the best starting point. This is because it emphasizes the specific role of website interface elements as a branding and sales channel between brand owners and current/future customers. In other words, the 7C's are the interface categories through which vendors communicate with their customers when delivering a core value proposition the company wants to convey. Rayport and Jaworski's 7C framework has previously been applied to other industries. Begalli et al. [4] conducted an empirical analysis of 272 high quality winery websites through an adapted version of Rayport and Jaworski's 7C framework. Lee, Oneng and Benbasat [28] and Georgiadis and Manitsaris [19] used Rayport and Jaworski's 7Cs as a reference framework for interfaces for mobile commerce and user interfaces. Yang et al. [48] extended the 7C to $8 \mathrm{C}$ and created a reference model for evaluating and designing effective Web 2.0 applications. Sabouri and Jalali [43] also investigated the 7C framework as a reference model for evaluating the Web 2.0 properties. Most recently, Yang et al. [48] presented the $8 \mathrm{C}$ framework as a reference model for analyzing collaborative Web 2.0 applications, including online social networking Web sites and online collaborative sites such as Wikipedia.

In line with these studies, we use the $8 \mathrm{C}$ framework as a basis, and study the following eight assessment criteria:

\section{- $\quad$ Content (Branding/Operational/One-way)}


- Community (Branding/Operational/Two-way)

- Communication (Branding/Innovative/One-way)

- $\quad$ Collaboration (Branding/Innovative/Two-way)

- Connection (Sales/Operational/One-way)

- $\quad$ Commerce (Sales/Operational/Two-way)

- $\quad$ Context (Sales/Innovative/One-way)

- $\quad$ Customization (Sales/Innovative/Two-way)

In our discussion of the eight criteria/categories, we also provide our definition of the concepts, specifically indicating for each category: the extent to which that category is useful primarily for furthering branding or sales, whether the orientation is primarily operational or strategic, and whether the communication is predominantly one-way or two-way. We shall return to these three strategic choices in the development of our CUBE model in section 6.

\section{Our Methodology for Studying Luxury Fashion Brands}

Initially, the development of categories and subcategories was inspired by observation of the actual application of technologies adopted on websites, after which the applications were checked and validated by comparing them with previous observations of fashion brand websites in the literature [35], [44]-[45]. The observation of luxury fashion websites, as such, was not guided by a predefined framework in 2006, but it was found to fit into the Yang et al. [48] 8C framework when studies were repeated in 2008, 2010 and 2012. In 2010 the subcategories were further extended according to recent advances in technologies, including augmented reality and 3D in the category context, as well as social shopping and shop able videos in the category commerce. In addition, one observation field code was changed, namely, the sub-category syndication in the category connection. In order to observe syndication in 2008, the two sites, shopstyle.com and vogue.tv, were selected due to their luxury fashion target market. However, in 2010 the syndication phenomenon exploded, and thus a general measure was used instead, measuring the brand on www.vitrue.com's social media index, which is an index score comprised of various mentionings from blogs, sites, and social network sites.

The observations of luxury fashion brand websites were conducted over a two week period in 2006 (of 25 brands), in 2008 (30 brands), in 2010 (33 brands) and in 2012 (15 brands) by one of the authors. The 2010 and 2012 surveys were further validated by a research assistant, who in 2010 initially found a $12 \%$ inconsistency in the observations and in 2012 a $6.8 \%$ inconsistency. This was mainly due to different interpretations of the websites and degree of user interaction possible on the site. All inconsistencies were reviewed, and the classifications were adjusted accordingly.

In total, 15 brands were included in all four observations: Burberry, Chanel, Chloé, Dior, Donna Karan, Gucci, Hermes, Louis Vuitton, Marc Jacobs, Mulberry, Paul Smith, Prada, Ralph Lauren, Valentino and Versace. The remaining 10 to 18 websites studied in the three surveys were used to validate conclusions, such as whether some sub-categories were generally absent in all luxury fashion brand websites or whether a particular sub-category was best business practice, etc.

Furthermore, 16 in-depth interviews were conducted to evoke attitudes and opinions of luxury brand professionals in order to collect information based on insider experience and privileged insights. This helped understand the why, how and what of luxury fashion brands using different Internet branding activities [26]. In 2006 four interviews were conducted with brand managers (Burberry, Mulberry, Tanner Krolle and Jean Muir). In 2008 nine interviews were conducted with brand managers (Fabergé, MCM and Richemont), Internet professionals (Limestone, FAST and Microsoft), and fashion website professionals (Skywire, Galle and Winkreative). The interviews were conducted faceto-face or over the telephone. In 2010 three interviews were conducted face-to-face with brand managers (Fabergé, Chanel and Boucheron).

Finally, in 2010 for the third survey, the CUBE framework was developed, and the $8 \mathrm{C}$ categories were theoretically defined in detail together with the definition of the sub-categories to be measured. The fourth survey, in 2012, was used not only as further evidence of the value of the CUBE framework and as an evaluation of it standing the test of a longitudinal study over several years, but also as illustration of the ability of the framework in capturing the changes taking place when the websites were maturing. 


\section{Assessment of Luxury Fashion Websites}

Our analysis of the results in the four surveys for each of the eight categories and sub-categories is described below. The definitions of the eight categories and 29 sub-categories that applied to luxury fashion brands are given in Appendix A. The actual data are shown in Appendix B, where a total count for each sub-category provides an illustration of the direction of the level of adoption of the different sub-categories over the four surveys in 2006, 2008, 2010 and 2012.

In the discussion below, we provide specific examples of noteworthy developments for each category over the four years $(2006,2008,2010$ and 2012). We further provide quotes from the interviews with luxury fashion brand managers to further illustrate the changes. Finally, in order to clarify the nature of the concepts, we have indicated whether the concept is primarily focused on: 1) enhancing branding or sales, 2) applying a one-way or a two-way perspective and 3) whether it may be characterized as primarily being operational or innovative. Since we believe that the strategic choice between branding and sales is the most important one, we shall report the findings starting with the four branding categories and continue with the four sales categories.

\subsection{Content (Branding, Operational \& One-way Interaction Mode)}

The category Content is defined as the offering mix, which includes product information, special campaigns, brand messages, brand history and corporate information (see Appendix A).

There has been a substantial development of the manner in which luxury fashion brands use product descriptions. In 2006 brands offered very sparse descriptions, and sometimes even just product codes. This has changed to a more descriptive lifestyle text where products at best are described as a sales assistant greeting the customer entering a physical store: with feelings, atmosphere and a tone of voice characteristic to the brand. It is evident that brands that focus on e-commerce (i.e., Burberry, Louis Vuitton, Mulberry and Paul Smith) have invested more in developing product descriptions.

Traditionally, luxury fashion brands have placed much emphasis on their history and timeline, with most brands including a section on their website dedicated to history in 2006 and 2008. However, in 2010 and 2012, history typically did not any longer necessarily have a separate section on the website; rather, it was integrated into the overall communication. On the other hand, while only a few brands offered corporate information in 2006 (33\%), this was increasingly offered in 2008 (40\%), in 2010 (47\%) and in 2012 (73\%).

Special promotions or campaigns on websites are the equivalent to the shopping window of a brick and mortar store, which is changed often (or at least seasonally) in order to give newness to the shop and attract visitors (see Appendix A). In 2006 and 2008, where the brand's websites often functioned like a catalogue, there was no newness offered, but in 2012, this has dramatically changed. Currently, all brands launch campaigns and promotions regularly.

\subsection{Community (Branding, Operational \& Two-way Interaction Mode)}

The category, Community, is defined as either the brand's own community within its own website or community on external platforms such as Facebook and Twitter, where connoisseurs and fans can discuss the brand (see Appendix A).

This is the category where there has been the greatest development over time. In 2006 and 2008 there were no own branded community sites, but in November, 2009 Burberry launched Art of the Trench. Gucci also launched Eye Web in 2009 and Gucci Connect in 2010. Hermes launched Jaimemoncarre (I love my scarf) in 2010, and brands such as Mulberry, Paul Smith and Smythson launched blogs, where readers could comment and interact with the brand. In contrast, Ralph Lauren, Louis Vuitton, Jimmy Choo, Dunhill, Donna Karan, Dolce Gabbana and Chanel launched blogs and news channels without the possibility of commenting. This is inherently contradictory to the whole idea of blogs, illustrating the dilemma of brands opening up for a potential loss of total control of their brand.

Likewise, there has been a strong development in the way in which luxury fashion brands adopted social media platforms such as Facebook, Twitter and YouTube. In 2006 none of these platforms was generally used. In 2008 all the observed brands had videos on YouTube - although not yet through branded YouTube channels - and most brands (90\%) had a Facebook account. However, these external sites were not managed and utilized very well. Most brands only had a logo as profile picture and nothing else developed in terms of content, pictures and specific features. Hermes did not even control their own Facebook profile, where there were 280 individuals pretending to be Hermes. Brands such as Donna Karan and Mulberry had only around 1,000 fans; whereas Calvin Klein, Ralph Lauren and Dolce Gabbana had around 100,000 Facebook fans. By 2012 Burberry managed to grow its direct fan base into 13.5 million fans, and Gucci, Dior and Louis Vuitton each had around nine million fans. 
In 2010, brands such as Valentino and Prada had still not taken control of their Facebook page, leaving the profiles in the hand of spammers. However, in 2012 all brands had a Facebook page and the majority of brands posted something new every day. An interesting development is that $80 \%$ of brands in 2012 linked directly from their website to their social media sites (Facebook, Twitter, YouTube and sometimes also Pinterest, Instagram and Google+) that were often in the visible menu bar (up from $20 \%$ in 2010). This indicates that social media has eventually become an integrated part of the online branding and communication.

\subsection{Communication (Branding, Innovative \& One-way Interaction Mode)}

The category Communication is defined as site-to-user communication, i.e., the possibility of website viewers receiving emails and newsletters, as well as viewing broadcasts, videos and interviews with brand figure heads on the site (see Appendix A).

All observed brands offered the option of signing up for newsletters in 2012. This is an important way to communicate directly, which counts for around $10 \%$ of traffic generation [10]. Another sub-category that changed significantly over the six year period was the prominent placement of the email register. In 2010 and 2012 the important sign-up button was placed in the menu bar, meaning that it was clearly visible on all individual sites. Contrastingly, brands seemed to fluctuate in whether or not to display traditional web-information such as about us and contact details. In 2006 nearly three quarters (73\%) of the observed brands shared contact details in the form of phone number, email or postal address. In 2010 less than half (47\%) of brands shared about us and contact details, whereas in 2012 the majority of brands (87\%) shared contact details. Accordingly, after a period of playing hide and seek with website viewers, only brands that did not offer e-commerce, such as Chanel, did not offer any contact details at all.

In 2008 half the brands (53\%) used videos as a communication tool showcasing interviews with designers, craftsmen or celebrity ambassadors. Donna Karan, Paul Smith and Tods had video interviews or messages from their designers. Ralph Lauren had interviews with celebrities describing their favorite moments with the brand. Despite video content claimed to be the most important and compelling content in fashion [31], [34], observations in 2010 indicated that fewer brands (40\%) were utilizing video interviews on their websites. However, in 2012 all observed brands (100\%) utilized videos, and Burberry, Louis Vuitton and Gucci even showcased product videos, seemingly making the product come alive on screen.

Martin Mason, CEO at MCM, explained that through video interviews, users could get a unique feel for the brand and be invited into the world of the brand. Videos give a different experience to reading; you are living in the visual experience and you are being entertained. This means you are seeing the way the designer moves, talks and what her personality is like. This is something that cannot be explained in words and something that is exclusive to the website and helps bring it to life.

\subsection{Collaboration (Branding, Innovative \& Two-way Interaction Mode)}

The category collaboration is defined as website user involvement in designing and developing fashion products, including providing feedback and comments on brand related issues (see Appendix A).

In 2006 and 2008 the luxury fashion brand websites had no collaboration related to design, co-creation, feedback or comments regarding product development. In 2010 Smythson and Ralph Lauren involved their customers in designing fashion products on their site. At Ralph Lauren customers could design their own Polo shirt (shape, color, initials, badges, etc.), and at Smythson customers could design their own stationary paper and have their initials or text engraved in the leather stationery items.

Fendi, Gucci and Marc Jacobs had a function on their websites where visitors could like the individual products, which consequently gathered a pool of likes and helped other visitors see which products were most popular amongst fellow visitors.

In 2010 the observation of the category collaboration was extended to Facebook and Twitter, i.e., observing how brands open up for feedback, comments and collaboration on Facebook. As recent as in 2010, none of the observed brands replied to customer comments, but in 2012 half (47\%) of the brands did. Facebook would, as such, also have a customer service function. Burberry's Creative Director, Christopher Baily, posted a video once a month greeting Burberry's Facebook fans, replying to some of the comments and stressing how much the customers meant to Burberry. Similarly, Marc Jacobs's CEO, Robert Duffy, took over the brand's tweets for a month leading up to their fashion show in the autumn of 2010. He tweeted some very personal messages about the business, posting pictures of the seamstresses, designers, cutters and models, while in parallel he was answering the tweets he received from followers. Marc Jacobs' Twitter profile grew from a few thousands followers to 75,000 in 2010 , and it continued to grow to 725,000 in 2012 . 
The Internet Retail Development Manager at Chanel, however, still had concerns about interacting with fans and allowing their unfiltered feedback: It's really difficult to control your brand in the social media. Brands are afraid of what people say and how they interact with the brand. You can only really control the brand on your own website.

While the first four categories were predominantly branding, we shall now turn to the four categories concerned with sales, the first of which is Connection.

\subsection{Connection (Sales, Operational \& One-way Interaction Mode)}

The category Connection is defined as links to external sites that use either microsites or there is content from external sites, including syndication of branded content (see Appendix A).

In 2012, brands were, to a large extent, linking traffic from their own sites to their own social media platforms, increasingly integrating the brand platforms online. They were also increasingly taking control of their own online sales channel, instead of linking to third party selling sites such as eluxury, Net a Porte, and Neiman Marcus, as they did in 2006.

The phenomenon of syndication (i.e., placing branded content or products on other sites) had not emerged in the fashion industry in 2006, but in 2008 the majority (87\%) of brands used syndication, and in 2010 and 2012 all brands used it. The most widespread use has been achieved by Gucci, Chanel and Burberry, who are also the more active on social media platforms and have many Facebook Likers - meaning many people and stakeholders spread the word of the brand and act as online brand ambassadors.

\subsection{Commerce (Sales, Operational \& Two-way Interaction Mode)}

The category Commerce is defined as the full set of e-commerce functionalities/features, including shopping assistants, virtual stores, shop able videos, and commerce on social media sites (see Appendix A).

In 2006 a quarter of the brands observed offered e-commerce in the UK and half of the brands offered e-commerce in the US, although the majority offered only a small selection of accessories (only Paul Smith offered a selection of clothes as well). In 2008 more than half $(60 \%)$ of the observed brands offered e-commerce on US commerce sites. Burberry, Hermes, Paul Smith and Mulberry were amongst the few brands that offered e-commerce to multiple countries. In 2010 there was a significant difference; more than three quarters (80\%) of the observed brands offered e-commerce to US, UK and most of EU. There was no increase in e-commerce uptake in 2012, and Chanel, Versace and Chloé still did not sell online; however, there was a large increase in the geographical roll-out of ecommerce, as most brands now shipped globally. The majority of brands offered both accessories and clothes, except from Dior, Louis Vuitton and Prada, who offered accessories only.

Ralph Lauren was the only brand offering a virtual flagship store with immersive and engaging lifelike shopping, as in gaming environments with the Home Alpine Lodge collection. Here, the visitor could move around in a beautiful ski chalet, click on the interior, get product information and send a purchase request. Cartier had a navigational virtual store with a shopping assistant showcasing and explaining the products in 2008, and Victor and Rolf had a navigational tour of the house, shows, library, etc. However, none of these offered the option to actually buy the products on display. In 2010 Gucci launched a so-called "digital flagship store" [39], and Marc Jacobs launched a virtual store where the visitors were welcomed by a man (a drawing) opening the door and different shopping assistants (drawings) at each product station. In 2012 this was changed again to a more mainstream online store set-up.

Burberry was the only brand that offered an online 24/7 shopping assistant chat function in 2012, even though it would seem like a basic customer service function in other industries such as home ware and electronic businesses. A third of the brands (33\%) in 2008 claimed to have shopping assistance via phone, e-mail or a fill-in form. In 2010 the majority (80\%) claimed to have shopping assistance available; however, when we tested the Gucci contact form, it took more than two weeks to get a reply to a product question. In 2012 the brands had extended customer service opening hours, they provided faster response rates, and $20 \%$ were open around the clock.

Mark Dunhill, CEO at Faberge, talked strongly about bringing the human touch to the online platform, The online experience and service needs to be as special as in the physical store. Sales advisors can help retain the emotional and otherworldly experience of the brand and the product. Technology provides the opportunity to entertain and connect with your customer - and to service your customers 24/7 around the globe.

In 2010 Ralph Lauren was the first to offer a shopable video RL Gang, which was an immersive storytelling video of kids going to school, where the viewer could click on the clothes in the video and be directed to the chosen product's URL where it could be purchased. In 2012, Gucci and Burberry also offered campaign videos with a quick shop feature, which made the video shopable. 
Many retailers like Barneys, Next, and online fashion shops such as ASOS have launched social commerce or Facebook commerce, i.e., selling their collections directly through their Facebook page. However, only one of the brands observed, Louis Vuitton, offered this function on their Facebook page with completion of sale on their own website in 2010. Nevertheless, in 2012 two thirds (73\%) of the observed brands utilized social shopping in a related manner; they added a share button next to products on their website, thus enabling visitors to share the product on their social media profiles.

\subsection{Context (Sales, Innovative \& One-way Interaction Mode)}

The category Context is defined as the way in which the site is organized and presented to the user. This includes Flash, videos, animations, augmented reality and 3D or 360 degree view of products (see Appendix A).

There was a significant change in the use of Flash on luxury brand websites. In 2006 nearly three quarters (73\%) of the observed brands used Flash; in 2008 all brands (100\%) used Flash, but in 2010 some brands had steered away from flash again. In 2012 only a third of the brands utilized Flash. Flash was traditionally used because of its lively and interactive qualities, but Flash is not viewable on iPhones and iPads, prohibiting the viewer from accessing the sites on these increasingly popular and important devises [31]. The brands that are still using Flash on their website in 2012 (e.g., Louis Vuitton and Mulberry) have a mobile version on their site or an app in order to allow users to interact with their brand on all devices.

Only half of the brands observed used video sub-categories (fashion shows, brand or campaign videos) on their websites in 2006, whereas the majority of brands used the video sub-categories in 2008, 2010 (80\%) and 2012 (100\%). The videos are all very stylized and controlled. They are inherently not video posts, blogs or interactive videos, where the brand can talk directly to fans and customers as exemplified on social media platforms (i.e., Burberry's video posts to Likers on Facebook). Burberry furthermore utilized an interactive 3D video on its site in 2010 where the user could drag the models and products in all directions on the screen creating a very engaging and entertaining interaction.

Recently, automobile and jewelry luxury brands such as BMW, Faberge, Tissot, and Boucheron have adopted augmented reality technologies in order to give shoppers the possibility of trying on products, achieving a more reallive feel, and making the product come live on the screen. However, this adoption of technology has not reached the luxury fashion brands as yet. Berta de Pablos, Global Director of Marketing \& Communications at Boucheron, talked about her experience utilizing augmented reality, saying, You have to start with the brand, not the technology. You have to ask, how can we create the dream of the brand in the minds of the consumers?.... The Internet can be a catalyst of emotions. We experienced that people were intimidated going into our stores, but we wanted them to interact and connect with the brand. Augmented reality allowed for this to happen.

Photo technology, such as 3D scanning of products, enabling a visitor to turn the product around - just as though she had it in her own hand - is now increasingly popular on e-commerce stores. Brands such as Nike and Apple, as well as online fashion stores such as ASOS and Net a Porter use this technology, as it enhances the buying experience and hence the conversion rate significantly. In 2010 none of the observed luxury fashion brands utilized the 3D technology or 360 degree views, but in 2012 Valentino used 360 degree product view and Burberry used 360 degree view via video.

\subsection{Customization (Sales, Innovative \& Two-way Interaction Mode)}

The category Customization is defined as personalization of the website, i.e., log-in and recognition of the user's preferences, or the possibility of customization or personalization of products (see Appendix A).

Product customization and personalization were the origin of luxury products; it was all about the individual and intimate relationship between the designer, craftsman and the customer. The Internet offers the opportunity of connecting with the individual customer in this unique and intimate manner again. There are, however, very few luxury brands which make use of this opportunity. In 2008 only Smythson and Ralph Lauren offered customization (where customers are involved in the design of the product) and personalization (where customers can add their initials or personal mark). In 2010 Louis Vuitton offered customization on their website and on their Facebook profile, and in 2012 Prada offered the option of putting one's initials on the shoe bag or on selected bags and backpacks. However, Burberry was the only brand observed that offered a full customization of its trench coat with more than 80,000 different design options.

The technology which recognizes the user is widely used by e-commerce sites, such as Amazon (books and consumer goods), Tesco (groceries), New Look and H\&M (high street fashion), for offering a personal experience on the website, but luxury fashion brands are generally not first movers. In 2006 no brands offered a sign in feature. In 2008 , only a few of the observed brands offered this feature, and it was not until 2010 where more than half $(60 \%)$ and 2012 where two thirds (73\%) of brands offered a log-in feature, thus enabling the brands to recognize the visitors who logged in. 


\section{Longitudinal Analysis of Fashion Brands Online Strategic Choices}

One of the unique aspects of this paper is that it has been possible to validate the use of the eight categories and 29 sub-categories through a longitudinal survey in each of the four years of 2006, 2008, 2010 and 2012 of the websites of 15 luxury fashion brands. In the previous discussion of each of the eight categories where it was particularly relevant, we discussed some of the developments from one survey to the next, but here it is done systematically.

The figures 1-3 below show the development regarding the three strategic choices:

- $\quad$ Only branding or enhancing with sales

- Only operational or enhancing with innovation

- Only one-way or enhancing with two-way communication

For all three binary strategic choices there is a very clear tendency that more and more fashion brands have adopted the advanced functionality over the period. All brands have the basic functionality regarding branding, operational and one-way (except Prada in 2006, as they did not have a website before 2008), and there was a clear growth in the number who augmented their website from branding to include sales, from being purely operational to also becoming innovative, and from being only one-way in 2006 towards becoming two-way. Especially the development from 2008 to 2010 and again from 2010 to 2012 is noteworthy. In this latter period, luxury fashion brands were closing the previous gap between what customers expected from brands, and what their websites were able to offer regarding social interaction, two-way interaction mode and a personalized relationship with the brand [33], [35], [44][45].

We shall now look at each of the three strategic choices in more detail. The first strategic choice is whether only to offer the traditional branding or to start selling from the website. Figure 1 shows the development over the four surveys in the number of websites. As we can see, there is a substantial increase in the number of fashion brands moving to a transactional stage (actually providing an e-shop), providing an e-shopping assistant and providing digital tools such as shop able video and social commerce in 2010. Brands have launched e-commerce in more countries in 2012, as well as widened their offering from a small selection of accessories to including clothing which traditionally was seen as impossible to sell online, as customers would not be able to get a sense of the size, fit, touch and feel through the computer screen.

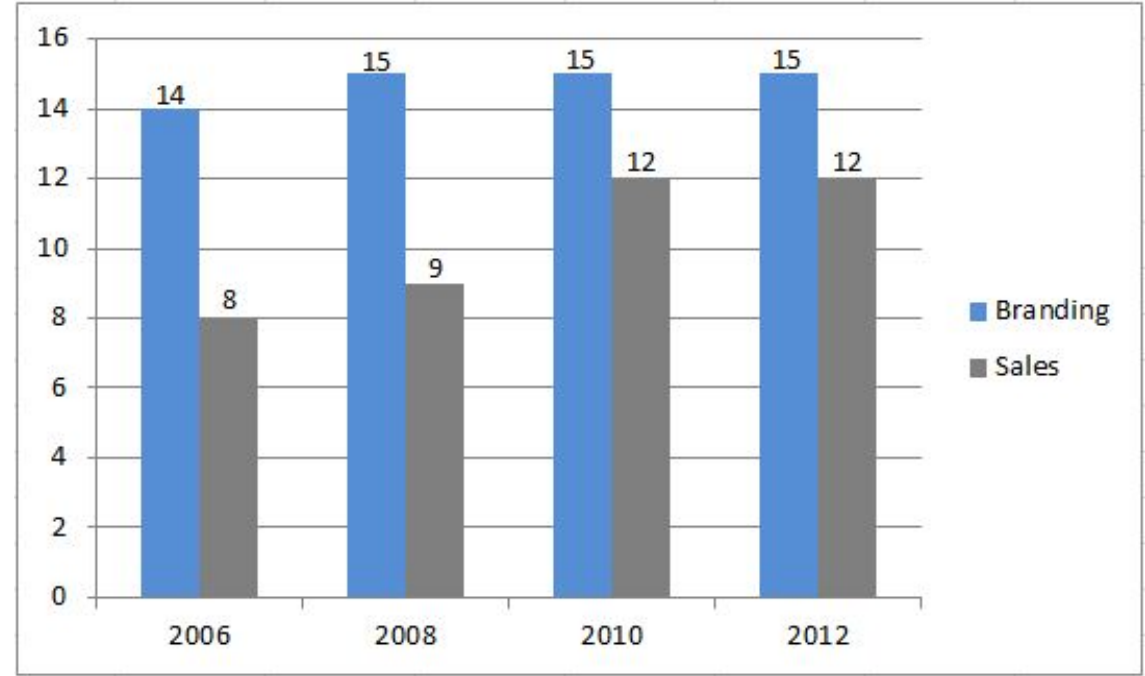

Figure 1: Comparison of strategic website usage in the years 2006 - 2012. Purpose: Branding and/or sales

In Figure 2, we are looking at the second strategic choice of whether to stay with the traditional one-way communication or to invite consumers to interact with the brand using two-way communication. As we can see, this came off to a slow start in comparison with other industries. None of the brands had opened up in 2006 and only two had embarked upon the two-way interaction mode in 2008, but the sharp rise in the 2010 survey is noticeable, where no less than 11 of the 15 brands adopted the opportunities of the social media platforms. In 2010 several brands started to interact, share, collaborate and receive feedback from consumers. The sub-category brand community also shows a significant increase in brand's creation of their own communities such as Burberry's Art of the Trench, which had a huge uptake with more than 3 million fans in 2010 and continued to grow 60\% per year. In 2012 more 
brands now choose to interact with consumers on their social media platforms, where previously they were notoriously and exclusively one-way communicative.

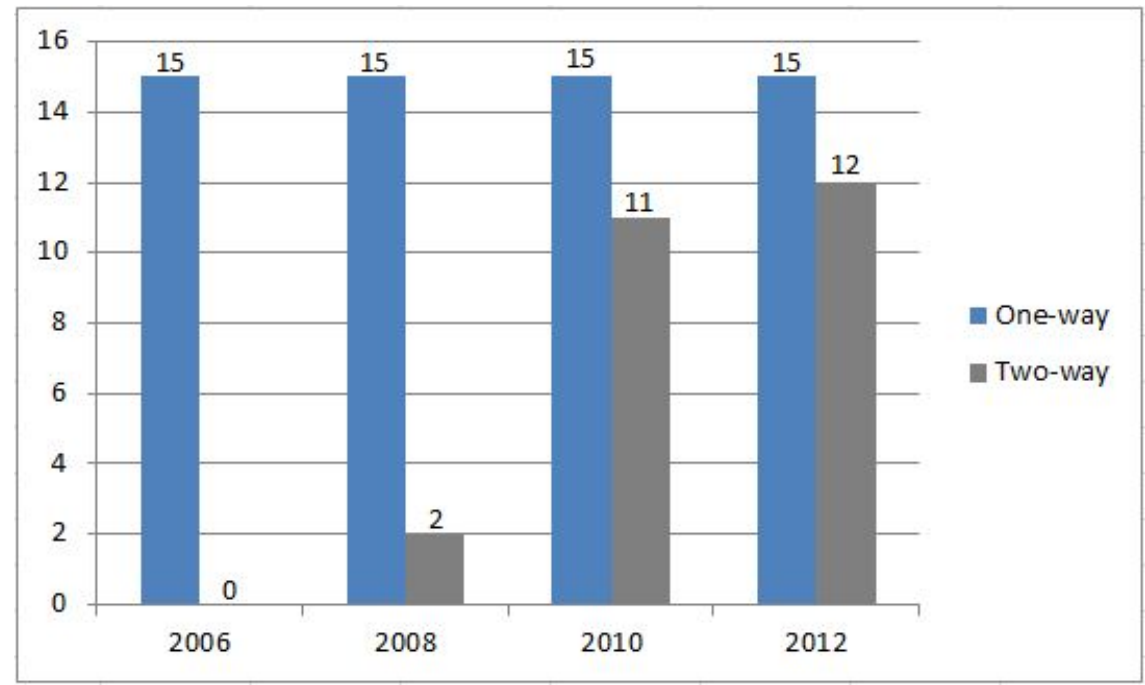

Figure 2: Comparison of strategic website usage in the years $2006-2012$. Interaction mode: One-way or two-way

The third strategic choice relates to the extent to which fashion brands are doing the bare necessities or whether they are actively pursuing innovation on the website. As illustrated in Figure 3, none of the fashion brands was classified as being innovative in 2006 when compared to other industries. There was an especially slow take up of new technologies, such as augmented reality, 3D, within the category Content and virtual stores within the category Commerce. No luxury fashion brands in our survey had adopted these technologies in 2010, even though luxury jewelry brands successfully had done so. However, in 2012 two of the brands in our survey showcased products via 360 degree views and one brand had launched a virtual store for one of its collections.

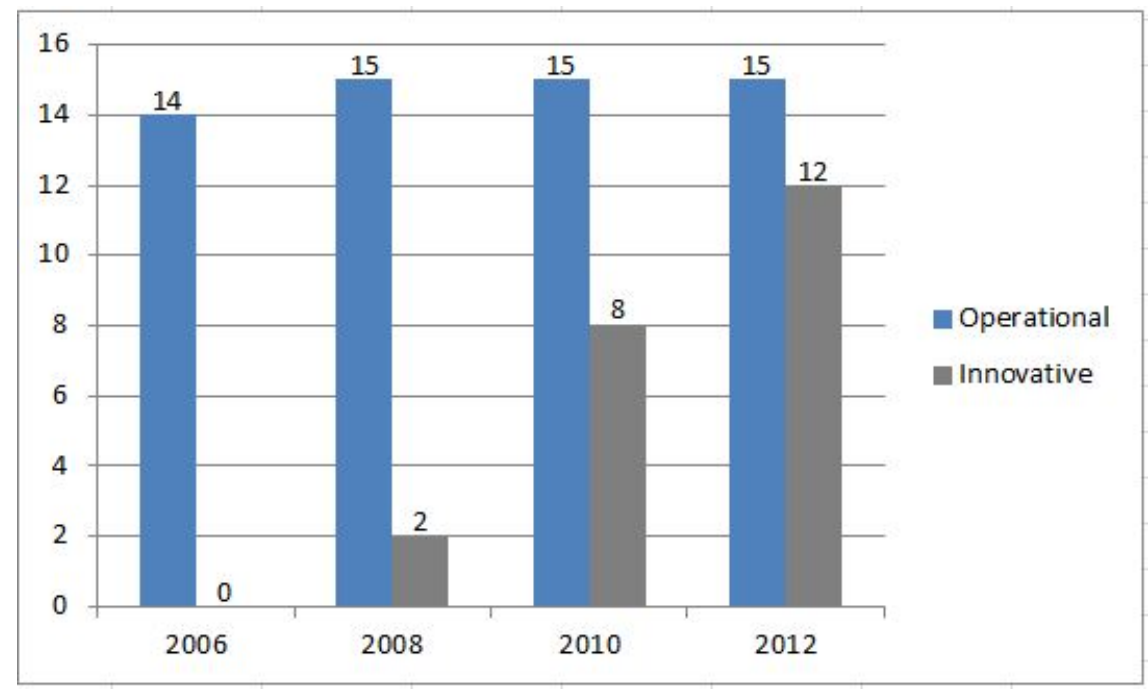

Figure 3: Comparison of strategic website usage in the years $2006-2012$. Orientation: Operational or innovative

Interestingly, the expert interviews in 2010 showed an intention to adopt interactive and social Web 2.0 tools to a higher degree than what was already implemented. The interviewees expressed that there were great opportunities to be harvested in all categories, which eventually would enhance the overall website experience and ultimately support brand experience and sales. Christopher Baily, Creative Director at Burberry, summed this up perfectly at a fashion show in September 2010: We are now just as much a media-content company as we are a design company, because it is part of the overall brand experience [2]. Burberry, to a large extent, tributes its strong growth of $30 \%$ during the financial crisis to their digital innovation as a key element in their 2012 strategy, stating: Burberry.com enabled more consistent brand projection across all customer touch points, leveraging its brand content to engage and connect consumers globally while still supporting retail sales as a global inventory pool (Burberryplc.com).

Last, we would argue that the lack of contact details and the lack of two-way interaction on websites and social media sites indicate that luxury fashion brands are still cautious about too close interaction. Most of them have as 
their number one priority to continually control the images and messages they push out to their customers and fans. Consequently, interaction does not flow both ways; it is still predominantly a one-way interaction mode, dictated by the brands that are afraid of what their customers and fans might say about them. This is in strong contrast to previous research findings on consumer's wishes and wants [35], [44]-[45] and is contrary to how consumers in general are empowered by interactive and social media. Consumers expect to define their own perspective on companies and brands, thus shifting the balance of power from company to customer [5]. Henceforth, luxury fashion brands have to do a better job at creating dream value by providing exceptional experiences online with the help of digital technologies and by interacting with consumers online [33].

\section{Development of the CUBE Framework for Development and Evaluation of Websites}

Strategic choices are important because the purpose and objectives of different websites obviously call for different criteria of assessment when websites are multidimensional in nature [20]. While CNN and Time Magazine aim at keeping the user for as long as possible, Google and airline portals such as Momondo.com aim at providing a solution in the shortest possible time to enhance the ease of use. While some portals, such as Amazon.com, aim at selling as much as possible, other sites, such as national tourism portals, aim at entertaining and informing users. Hence, even though the assessment framework might be the same, it is not clear that having more is better than having less, It all depends on the strategic objectives of the website.

As indicated earlier, all existing frameworks for evaluation of websites, including the $8 \mathrm{C}$ framework, which we have used here thus far, have been developed bottom-up, categorizing functionalities/features that can be identified empirically through externally assessing company websites, identifying best business practices, and relying on rules of thumb and opinions of a range of experts. These frameworks consist of independent categories that have been consolidated into a type of checklists without any kind of formal overall rationale, strategy or theory for choosing one category over others. Indeed, none of the reported studies presents a theoretical background for the identification/selection of the categories, nor has any explicitly discussed the strategic purposes for the website design evaluated. It is the ambition of this paper to contribute to the development of a theoretically based framework evaluation of commercial B2C websites, which explicitly builds on strategic choices in website design. We shall develop this for the luxury fashion brands, but we believe it will have value far beyond this industry.

To achieve this, we decided to start top-down by identifying the three key strategic choices that developers need to take as a starting point in developing and managing B2C company websites.

\section{Purpose (branding or sales)}

\section{Mode of interaction (one-way or two-way)}

\section{Orientation (operational or innovative)}

The first strategic choice relates to the purpose of a B2C website. In the early strategic literature, for example, the Value Chain, one of the five primary functions is called Marketing and sales [38] and is identified as being the most important function for consumers. Early authors on e-commerce and e-business (e.g., Kalakota and Robinson, 1999 [23]) made it clear that there was much more to the Internet than just e-commerce. Don Tapscot wrote in the foreword of his book that "most managers still view e-business and e-commerce as buying and selling of goods on the Internet...[but] it is much more than that." The more is first and foremost marketing. However, while marketing was not a separate topic in the early book by Kalakota and Robinson in 1999, Internet marketing became a standard topic in textbooks on e-commerce from the early 2000's (see e.g., Chaston [11], Chaffey [8], Laudon and Traver, [27]). Marketing/branding is especially important when it comes to luxury brands, which from early times have used their websites to support branding and other marketing activities by showcasing catwalk pictures, advertising campaigns, displaying videos promoting the brand, encouraging dialogs about the brand, crowdsourcing ideas and co-creating new products with customers and fans (Chernatory and Christodoulides [12]; Christodoulides and Chernatory [14]; Keller [25]; Aghekyan-Simonian et al. [1]). Accordingly, we have identified the first strategic choice for B2C website within the fashion industry to be whether it focuses on branding (including marketing) on sales (including logistics in all dealings and CRM) or on both.

The second strategic choice is whether the mode of interaction is mainly a one-way, mass marketing tool (e.g., Kotler et al.), which could include a personalization or customization of the messages to the consumer, but is predominantly distributed from the brand to the customers. The alternative is two-way interaction, where individual consumers are enabled or even encouraged to engage in interaction [9]. The choice between these two modes of interaction is crucial. On the one hand, one-way mass marketing can be analyzed and controlled by the brand owner, and thus a high level of skills can be leveraged in this process and control of the brand is retained. On the other hand two-way interaction mode is increasingly becoming the norm rather than the exception when using the Internet for ecommerce, and it has become natural to open up for feed-back on the products on the website or social media platforms, and even to enable co-creation of ideas or innovations [36], [40]. 
The third strategic choice is less of a binary choice than are the other two choices. On the one hand, we have the fairly standard websites allowing for different types of operational functionalities/features (e.g., displaying of product or company information and ordering of goods from a catalogue), while, on the other hand, we find innovative strategic functionalities/features (e.g., augmented reality, customization of products and collaboration) closely linked to the overall strategic directions of the company.

In the discussion above and in the following development of the CUBE-framework, the strategic choices have been shown as binary, e.g., either branding or sales. Obviously, it is possible to combine the strategies and build a website to support both business strategies. One may, of course, also see middle forms, e.g., where the main purpose is that of sales, but where branding of own products is part and parcel of the sales process. However, when making strategic decisions and implementing these, there has to be clear objectives of: e.g., a full-fledged marketing effort for branding. Accordingly, when developing our CUBE framework below, we shall, for illustration purposes, treat each of the three dimensions as binary. But we recognize that there are several intermediary steps or even a continuum on these categories.

In section 3 of this paper, we have discussed the eight categories, and for each of these, as part of the definition of the categories, we have indicated whether we predominantly see the concept as branding or sales, one-way or twoway, and operational or innovative. If we combine the three strategic choices, we get $2^{3}$ or eight different combined strategies, e.g., two-way, operational and sales, which we have chosen to label commerce, or two-way, innovative and branding, which we have chosen to label collaboration. We have illustrated the eight different combined strategies below in Figure 4 with the CUBE-framework.

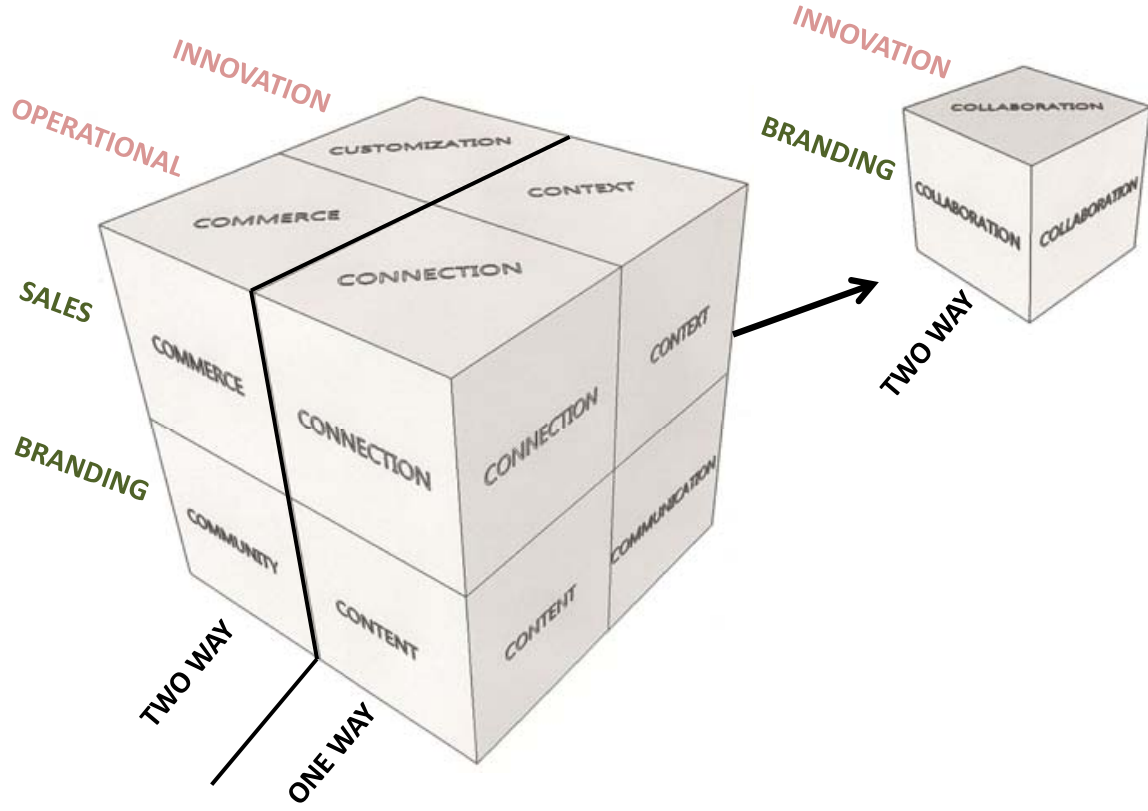

Figure 4: CUBE framework for assessment of websites - the hidden cube is shown next to the large one

More importantly, it has been possible to enter each of our eight categories into each of the eight small cubes within the larger cube. In the naming of the eight categories we retained the names of the original seven concepts originally proposed by Rayport and Jaworski [42], plus the category collaboration proposed by Yang et al. [48] to complement the criteria given to the emergence of social media, as described in section two.

In our research we have documented the value of this cube framework in two ways. First, we have documented how the eight individual categories with the 29 sub-categories have been useful in describing the diffusion and adoption of functionalities/features. This was done for the 15 luxury fashion brands that we studied in a longitudinal study through four surveys in 2006, 2008, 2010 and 2012, constituting in total a six year period. These surveys show that the framework is useful in characterizing the changes over the relatively short span of time, for example, how the use of Flash increased very fast, and then disappeared again. Furthermore, we could document the adoption of different innovative functionality/features, such as, e.g., how syndication was not done by anyone in 2006, but was used by all in 2012 , how recognition of the user was not used by anyone in 2006 , but by almost all in 2012, etc.

Second, we would argue the value of this framework for website developers when deciding on the overall strategy for a (new) website design. One can slice the cube in three different ways. For example, if the agenda is to enhance branding, there are four small cubes available in the bottom layer of the cube (community, context, communication 
and collaboration). If, on the other hand, the agenda is to improve on the operational performance, one would look for the front four small cubes (commerce, connection, community and content). Once that is determined, it is possible to drill down to investigate the details of each of the four categories in that half of the cube. Each category has sub-categories, and it is further possible to dig into each sub-category and learn what each of the 15 luxury fashion brands have done by accessing their website.

To summarize, we have extended the work of Yang et al. [48] in the following way. First, we have specifically chosen a brand owner perspective (instead of user or developer perspectives as applied in most studies), and identified the three strategic choices, which according to strategy literature would be important in designing and analyzing websites. Second, we have (partly) redefined the concepts (categories) to reflect the three strategic choices. Third, we have operationalized the $8 \mathrm{C}$ concepts through a set of two to six specific sub-categories for each of the eight concepts that might be observed when analyzing the websites. Fourth, we have specifically modified the subcategories to match the special characteristics of luxury brands. Fifth, we have carried out the longitudinal study of the status of the websites with four different surveys to document the robustness and value of the CUBE model. Finally, we have developed the cube framework to serve as a strategic tool in the design and assessment of websites.

\section{Conclusion}

Internet shopping is now exceeding more than $10 \%$ of retail trade in the most digitized economies, and marketing on the Internet (typically using Google AdWords) is now the largest advertising media, having surpassed the advertising revenue of newspapers, magazines and TV-advertising. A company in the fashion industry must develop, implement and further innovate its Internet strategy in order to retain and further develop its brand.

The first of our three research questions concerned relevant assessment criteria for assessment of luxury fashion brand websites. Based on a thorough literature study, we identified a large number of different studies, all of which were created bottom up and that basically studied what web-designers did and what characterized successful websites. The closest to a theoretically based assessment framework that we could find was the classification framework of $8 \mathrm{C}$ of Yang et al. [49], which turned out to be useful for characterizing intuitively which categories were likely to be the most important. However, in order to apply this, we needed to develop a set of sub-categories or specific measurements. These were hence developed, and the results are shown in Appendix A. This appendix also serves as definitions of the eight categories with their respective sub-categories.

In order to answer the second research question, we applied this framework to 15 luxury brand websites in four surveys in the years of 2006, 2008, 2010 and 2012, and in these surveys we were able to document the huge development in the websites partly due to development within Web 2.0 and social media, but also partly due to development in management thinking and strategies for reaching current and potential customers. The development and adoption in categories such as creating a brand community, inclusion of video content from catwalks, links to other websites, and possibilities for customization of products and identification of users, is quite remarkable. In this short period, we see the adoption and diffusion of these new technologies. But the survey also shows a large difference in the extent to which individual brands have adopted the options. Probably more than most other industries, the fashion industry is very uncertain as to whether, and how, to apply the opportunities offered by the Internet, primarily because of the challenge of maintaining control of their brand. More than any other industry, fashion brands are confronting the dilemma of maintaining the exclusivity while at the same time opening up for real two-way interaction mode and involvement of its customers.

Finally, our third research question is concerned with the development of a theory for websites design. Our early analysis of the characteristics of the eight categories showed that they could all be characterized as contributing to the three strategic choices: branding/sales, operational/strategic and one-way/two-way communication. Whether the individual category can be characterized predominantly as one or the other is written into the table in Appendix A. Readers might to some extent disagree with a few definitions of the $8 \mathrm{C}$ concepts. However, we believe that what is important is that we can show that the three strategic choices are relevant in relation to website assessment and to web-site design, and that strategic decisions regarding these three strategic choices will translate into specific requirements for $\mathrm{B} 2 \mathrm{C}$ websites.

Defining the three strategic choices as binary choices, even though in practice the situation might not be that clearcut, allows us to develop our theory called the CUBE framework; we believe this framework has substantial practical value as a starting point for a theory on website design. The illustration of the three strategic dimensions hopefully serves to illustrate the main issues, and our operationalizations of the eight triplets using the eight $C$-concepts has proven useful in identifying and differentiating between the strategies of the different brands within the fashion industry.

We suspect that the CUBE framework will be valuable beyond just the fashion industry, but we leave this to further research to demonstrate. 


\section{References}

[1] M. Aghekyan-Simonian, S. Forsythe, W. Suk Kwon, and V. Chattaraman, The role of product brand image and online store image on perceived risks and online purchase intentions for apparel, Journal of Retailing \& Consumer Services, vol. 19, no. 5, pp. 325-331, 2012.

[2] H. Alexander, Burberrys conquest of cyber space, The Daily Telegraph, vol. 8, no. 9, pp. 1-1, 2010.

[3] P. Auger, The impact of interactivity and design sophistication on the performance of commercial websites for small businesses, Journal of Small Business Management, vol. 43, no. 2, pp. 119-137, 2005.

[4] D. Begalli, S. Codurri, and D. Gaeta, Wine and web marketing strategies: The case study of Italian speciality wineries, British Food Journal, vol. 111, no. 6, pp. 598-619, 2009.

[5] J. Bernoff and C. Li, Harnessing the power of the oh-so-social web, MIT Sloan Management Review, vol. 49, no. 3, pp. 36-36, 2008.

[6] J Bughin, J Manyika, and A. Miller. (2008, July) Building the web 2.0 enterprise: A McKinsey global survey. McKinsey Quarterly Web Exclusive. [Online]. Available: http://www.fabiocipriani.com/wpcontent/uploads/2008/08/web20.pdf.

[7] J. Bughin and J. Manyika. (2007, January) How businesses are using web 2.0: A McKinsey global survey. McKinsey Quarterly Web [Online]. Exclusive. Available: http://www.skmf.net/fileadmin/redaktion/aktiver content/01 Events/080514 SWISS KM Tool Tag/Track 0 Ot her Material/0005 How firms use Web20.pdf.

[8] D. Chaffey, E-Business and E-Commerce Management: Strategy, Implementation and Practice. Harlow, England: Financial Times/Prentice Hall, 2002.

[9] D. Chaffey, F. Ellis-Chadwick, K. Johnston, and R. Mayer, Internet Marketing: Strategy, Implementation and Practice. Harlow, England: Prentice Hall, 2009.

[10] G. Charlton. (2011, February) Social media drives 3\% of traffic to e-commerce sites: Survey. E-consultancy. [Online]. Available: http://econsultancy.com/uk/blog/7120-social-media-drives-3-of-traffic-to-e-commerce-sites.

[11] I. Chaston, E-Marketing Strategy. London, England: McGraw-Hill, 2001.

[12] L. Chernatony and G. Christodoulides, Taking the brand promise online: Challenges and opportunities, Interactive Marketing, vol. 5, no. 3, pp. 238-251, 2004.

[13] W. C. Chiou, C. C. Lin, and C. Perng, A strategic framework for website evaluation based on a review of the literature from 1995-2006, Information \& Management, vol. 47, no. 5, pp. 282-290, 2010.

[14] G. Christodoulides, L. De Chernatony, O. Furrer, E. Shiu, and T. Abimbola, Conceptualising and measuring the equity of online brands, Journal of Marketing Management, vol. 22, no. 7-8, pp. 799-825, 2006.

[15] Economist Intelligence Unit, Serious business. Web 2.0 goes corporate, The Economist, London, England, Technical Report, 2007

[16] S. R. Elliot, A. S. Mørup-Petersen, and N. Bjørn-Andersen, Towards a framework for evaluation of commercial web sites, in Proceedings of the $13^{\text {th }}$ International Bled Electronic Commerce Conference, Bled, Slovenia, 2000, pp. 69-86.

[17] FDIH. (2012, August) Dansk e-handels analyse 2012. FDIH. [Online]. Available: http://www.fdih.dk/analyser/dansk-e-handelsanalyse-forbruger/2012/.

[18] A. M. Fionda and C. M. Moore, The anatomy of the luxury fashion brand, Journal of Brand Management, vol. 16, no. 5 , pp. 347-363, 2009.

[19] C. K. Georgiadis and A. Manitsaris, Personalization of user interfaces in e-commerce and m-commerce applications, in Proceedings of the International Association for Development of the Information Society on eCommerce, Lisbon, Portugal, 2005, pp. 195-202.

[20] A. Ghandour, G. Benwell, and K. Deans, Measuring the performance of e-commerce websites-An owner's perspective, Pacific Asia Journal of the Association for Information Systems, vol. 3, no. 1, pp. 1-27, 2011.

[21] E. Huizingh, A. Krawczyk, T. Bijmolt, and J. Hoekstra, How important are transactional or informational functions for website success?, in Proceedings of the 2007 Conference of the Australian and New Zealand Marketing Academy, Dunedin, New Zealand, 2007, pp. 3031-3037.

[22] M. Jennings, Theory and models for creating engaging and immersive ecommerce websites, in Proceedings of the 2000 ACM Special Interest Group on Computer Personnel Research Annual Conference, Chicago, Illinois, USA, 2000, pp. 77-85.

[23] R. Kalakota and M. Robinson, E-Business 2.0: Roadmap for Success. Upper Saddle River, N.J., US: AddisonWesleyl, 2001.

[24] J. N. Kapferer and V. Bastien, The Luxury Strategy: Break the Rules of Marketing to Build Luxury Brands. London, England: Kogan Page Ltd, 2009.

[25] K. L. Keller, Brand equity management in a multichannel, multimedia retail environment, Journal of Interactive Marketing, vol. 24, no. 2, pp. 58-70, 2010.

[26] S. Kvale and S. Brinkmann, Interviews: Learning the Craft of Qualitative Research Interviewing. London, UK: Sage Publications Inc., 2008.

[27] K. C. Laudon and C. G. Traver, E-Commerce: Business, Technology, Society. Boston, MA, US: Pearson/Addison Wesley, 2007.

[28] Y. E. Lee and I. Benbasat, Interface design for mobile commerce, Communications of the ACM, vol. 46, no. 12, pp. 48-52, 2003. 
[29] LSE and Novell, The 1999 World Wide Web 100 - Ranking the world's largest 100 firms on the web, 1999. London, UK: London School of Economics, 1999.

[30] H. Mintzberg, Patterns in strategy formation, Management Science, vol. 24, no. 9, pp. 934-948, 1978.

[31] H. Moghaddas. (2010, September) Luxury fashion retailers: functionality or flash?. The Retail Bulletin. [Online]. Available: http://www.theretailbulletin.com/news/comment luxury fashion retailers functionality or flash 2309-10/?keys=luxury\%20fashion\%20retailersThe\%20Retail\%20Bulletin.

[32] S. Muylle, R. Moenaert, and M. Despontin, The conceptualization and empirical validation of web site user satisfaction, Information \& Management, vol. 41, no. 5, pp. 543-560, 2004.

[33] U. Okonkwo, Sustaining the luxury brand on the Internet, Journal of Brand Management, vol. 16, no. 5, pp. 302310, 2009.

[34] U. Okonkwo, Luxury Online: Styles, Systems, Strategies. Houndmills, Bassingstroke, Hampshire, UK: Palgrave Macmillan, 2009

[35] F. D. O'Riley and C. Lacroix, Luxury branding on the Internet: Lost opportunity or impossibility?, Marketing Intelligence \& Planning, vol. 21, no. 2, pp. 96-104, 2003.

[36] M. Parameswaran and A. B. Whinston, Research issues in social computing, Journal of the Association for Information Systems, vol. 8, no. 6, pp. 336-350, 2007.

[37] Y. A. Park and U. Gretzel, Success factors for destination marketing web sites: A qualitative meta-analysis, Journal of Travel Research, vol. 46, no. 1, pp. 46-63, 2007.

[38] M. E. Porter, Competitive Advantage: Creating and Sustaining Superior Performance: With a New Introduction. New York, US: Free Press, 1985.

[39] PPR, PPR creates a new E-business development unit, Corporate Press Release, Paris, France, Technical Report, 2011.

[40] C. K. Prahalad and V. Ramaswamy, Co-creation experiences: The next practice in value creation, Journal of Interactive Marketing, vol. 18, no. 3, pp. 5-14, 2004.

[41] M. Quaddus and D. Achjari, A model for electronic commerce success, Telecommunications Policy, vol. 29, no. 2-3, pp. 127-152, 2005.

[42] J. F. Rayport and B. J. Jaworski, Introduction to E-Commerce. Boston, US: McGraw-Hill, 2003.

[43] M. Sabouri and A. A. Jalali, Evaluating web 2.0 services based on 7C framework, in Proceedings $6^{\text {th }}$ International Conference on Information Technology: New Generations, Nevada, USA, 2009, pp. 1693-1694.

[44] F. H. R. Seringhaus, Selling luxury brands online, Journal of Internet Commerce, vol. 4, no. 1, pp. 1-25, 2005.

[45] N. Siddiqui, A. O'Malley, J. C. McColl, and G. Birtwistle, Retailer and consumer perceptions of online fashion retailers: Web site design issues, Journal of Fashion Marketing and Management, vol. 7, no. 4, pp. 345-355, 2003.

[46] US Census Bureau News. (2013, May) Quarterly retail e-commerce sales ${ }^{1 \text { st }}$ quarter 2013. US Department of Commerce. [Online]. Available: http://www.census.gov/retail/mrts/www/data/pdf/ec current.pdf.

[47] T. A. Yang, D. J. Kim, and T. Vu, Capturing online collaboration in the design elements model for web 2.0 and beyond, in Handbook of Research on Web 2.0, 3.0, and X.0: Technologies, Business, and Social Applications (S. Murugesan, Ed.). Australia: IGI Global, 2010, pp. 647-661.

[48] T. A. Yang, D. J. Kim, V. Dhalwani, and T. K. Vu, The 8C framework as a reference model for collaborative value webs in the context of web 2.0, in Proceedings of the $41^{\text {st }}$ Annual Hawaii International Conference on System Sciences, Hawaii, USA, 2008, pp. 319-319.

[49] M. Zviran, C. Glezer, and I. Avni, User satisfaction from commercial web sites: The effect of design and use, Information \& Management, vol. 43, no. 2, pp. 157-178, 2006. 


\section{Appendix A: The 8C Framework Applied to Luxury Fashion Brand Websites}

\begin{tabular}{|c|c|}
\hline $\begin{array}{l}\text { Interface } \\
\text { categories }\end{array}$ & Applied to Luxury Fashion Brand Website Assessment \\
\hline $\begin{array}{l}\text { Content } \\
\text { Branding } \\
\text { Operational } \\
\text { One-way }\end{array}$ & $\begin{array}{l}\text { Definition: Enticing mix of product information and comprehensive brand information. } \\
\text { - Product information. Does the site offer detailed and engaging product } \\
\text { descriptions or only sparse information? } \\
\text { - History. Does the site offer a history section about the brand? } \\
\text { - Corporate information. Does the site offer corporate information related to the } \\
\text { brand? } \\
\text { - Special campaigns. Does the site have special campaigns or sections } \\
\text { functioning like a shop window which is changed seasonally? }\end{array}$ \\
\hline $\begin{array}{l}\text { Community } \\
\text { Branding } \\
\text { Operational } \\
\text { Two-way }\end{array}$ & $\begin{array}{l}\text { Definition: Communities established by the brand where fans interact with the brand and } \\
\text { each other. } \\
\text { - Own brand community. Does the site have a community section launched and } \\
\text { controlled by the brand itself? } \\
\text { - Community on external site. Does the brand have communities on external } \\
\text { social sites such as Facebook, YouTube and Twitter? And how many fans have } \\
\text { joined this community? }\end{array}$ \\
\hline $\begin{array}{l}\text { Communication } \\
\text { Branding } \\
\text { Innovative } \\
\text { One-way }\end{array}$ & $\begin{array}{l}\text { Definition: News, details and communication from the brand. } \\
\text { - Email register. Can the visitor sign up for newsletters on the site? } \\
\text { - About us I Contact. Is there an about us section and contact details for the } \\
\text { brand? } \\
\text { - Video interviews. Does the site have video interviews with the designer, brand } \\
\text { owner or perhaps fans of the brand? }\end{array}$ \\
\hline $\begin{array}{l}\text { Collaboration } \\
\text { Branding } \\
\text { Innovative } \\
\text { Two-way }\end{array}$ & $\begin{array}{l}\text { Definition: Collaborating, crowdsourcing and opening up for feedback from fans and } \\
\text { customers. } \\
\text { - Design collaboration. Is it possible to collaborate with the brand on either the } \\
\text { brand site or on Facebook? } \\
\text { - Feedback \& comments. Does the brand allow comments and does it interact } \\
\text { with customers on brand site or on Facebook? }\end{array}$ \\
\hline $\begin{array}{l}\text { Connection } \\
\text { Sales } \\
\text { Operational } \\
\text { One-way }\end{array}$ & $\begin{array}{l}\text { Definition: Connection to other complementing sites. } \\
\text { - Links to other sites. Does the site have links to other sites and external sites? } \\
\text { - Micro sites. Does the brand have sub-sites for i.e., campaigns or special } \\
\text { collections? } \\
\text { - Syndication. Does the brand have syndication of content (products, advertising } \\
\text { etc.) on other complementing sites? }\end{array}$ \\
\hline $\begin{array}{l}\text { Commerce } \\
\text { Sales } \\
\text { Operational } \\
\text { Two-way }\end{array}$ & $\begin{array}{l}\text { Definition: Shopping the brand's products on the website or brand controlled social media } \\
\text { channel. } \\
\text { - Transactional. Does the site offer e-commerce? } \\
\text { - Virtual store. Does the site have a virtual store which customers can walk } \\
\text { through and purchase from? } \\
\text { - Link to third party. Does the site have links to other sites which sell the brand's } \\
\text { products? } \\
\text { - e-shopping assistant. Does the site have a shopping assistant in the form of } \\
\text { - She chat, telephone line or live video advice? } \\
\text { - Social commerce. Does the brand offer e-commerce on their social media } \\
\text { platforms, such as Facebook or YouTube? }\end{array}$ \\
\hline $\begin{array}{l}\text { Context } \\
\text { Sales } \\
\text { Innovative } \\
\text { One-way }\end{array}$ & $\begin{array}{l}\text { Definition: Importance of beautiful and aesthetically pleasing design. } \\
\text { - Flash. Does the site use immersive Flash graphics or e.g., HTML? } \\
\text { - } \quad \text { ideos. Does the site have videos of fashion shows, of products, or any brand } \\
\text { related material? } \\
\text { - } \quad 360^{\circ} \text { view. Does the site offer } 360^{\circ} \text { view of the products, creating a live and } \\
\text { tangible feeling of the products through visuals and product rotation? } \\
\text { - Augmented Reality. Does the site offer augmented reality features which either } \\
\text { allow trying on the products or offer extra brand experience? (Only for 2010) } \\
\text { 3D. Does the site offer any 3D technology, enabling engaging interaction with } \\
\text { products, campaigns or other features? }\end{array}$ \\
\hline
\end{tabular}


Appendix A: continuation

Customization Definition: Customizing the site experience for the individual user.

Sales

Innovative

Two-way
- Product customization. Does the site offer the possibility of customizing products?

- Personalization. Does the site offer the possibility of personalizing products, i.e., adding initials to a product?

- Recognition of user. Does the site recognize the users? E.g., is there a sign in option? 


\section{Appendix B: B2C Website Assessment 2006-2012 (Shown in 3 Tables)}

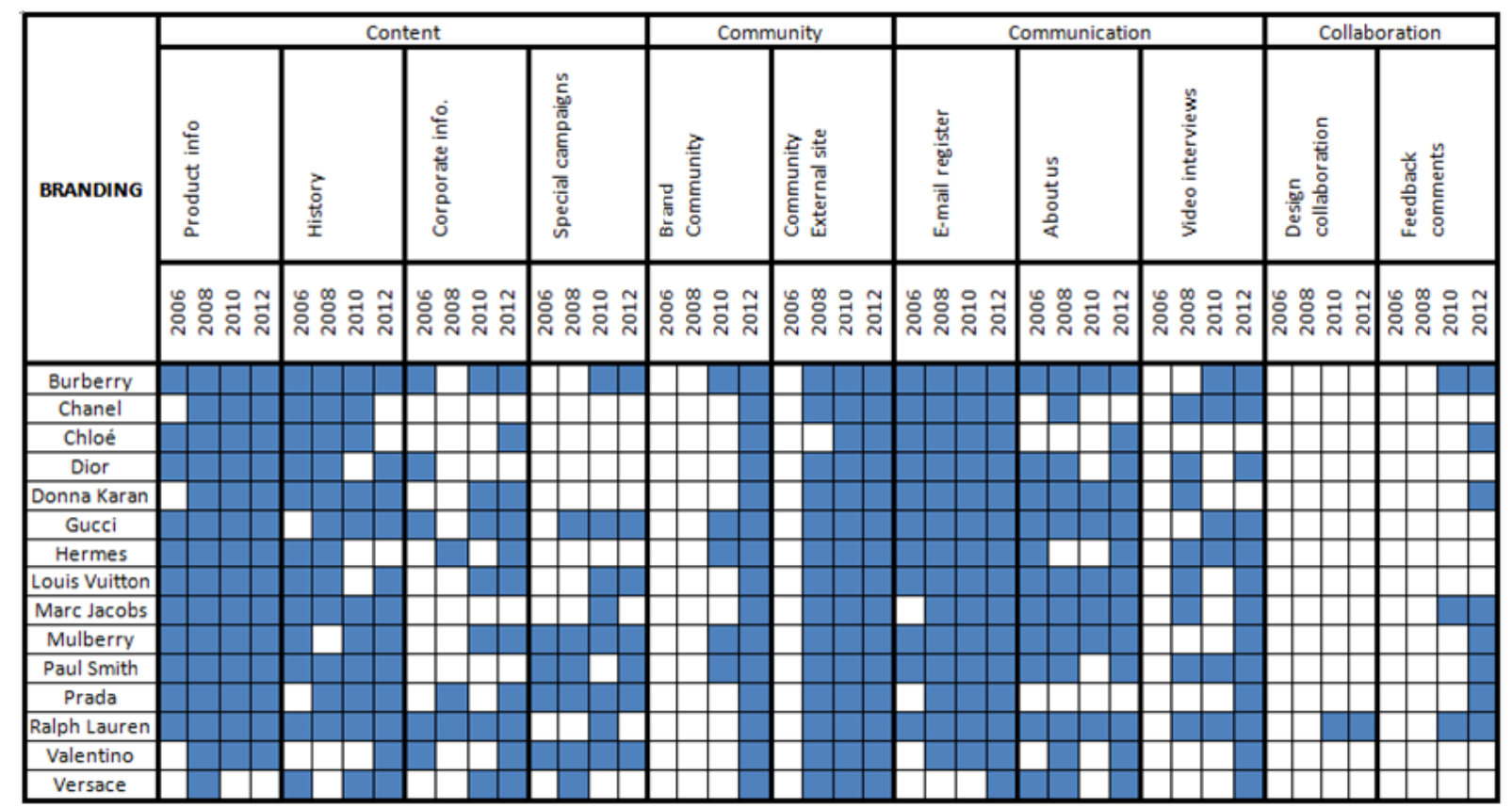

\begin{tabular}{|c|c|c|c|c|c|c|c|c|c|}
\hline \multirow{3}{*}{ SALES } & \multicolumn{3}{|c|}{ Connection } & \multicolumn{6}{|c|}{ Commerce } \\
\hline & 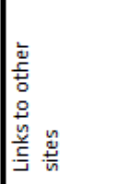 & 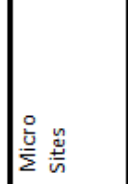 & 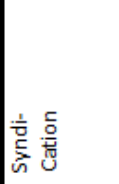 & 需 & 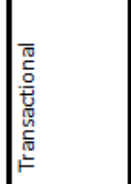 & 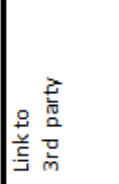 & 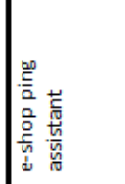 & 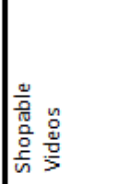 & 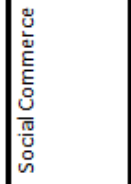 \\
\hline & 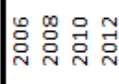 & 옹 & 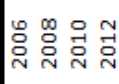 & 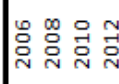 & 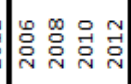 & 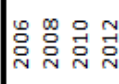 & : & 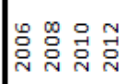 & 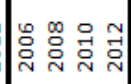 \\
\hline Burberry & & & & & & & & & L \\
\hline Chanel & & & & & & & & & 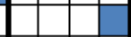 \\
\hline Chloé & & & & & & & & & T \\
\hline Dior & & & & & & & & 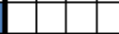 & \\
\hline Donna Karan & & & & & & & & & \\
\hline Gucci & & & & & & & & & 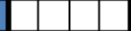 \\
\hline Hermes & & & & & & & & & \\
\hline Louis Vuitton & & & & & & & & & \\
\hline Marc Jacobs & & & & & & & & $\square$ & T \\
\hline Mulberry & & & & & & & & & \\
\hline Paul Smith & & & & & & & & & \\
\hline Prada & & & & & & & & & \\
\hline Ralph Lauren & & & & & & & & & \\
\hline Valentino & & & & & & & & & \\
\hline Versace & & & & & & & & & \\
\hline
\end{tabular}




\begin{tabular}{|c|c|c|c|c|c|c|c|c|c|}
\hline \multirow{3}{*}{ SALES } & \multicolumn{6}{|c|}{ Context } & \multicolumn{3}{|c|}{ Customization } \\
\hline & $\frac{\frac{5}{n}}{\frac{\pi}{L}}$ & 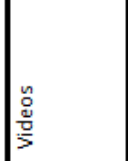 & 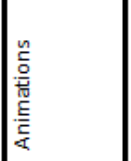 & $\begin{array}{l}3 \\
\frac{3}{3} \\
0 \\
0 \\
0\end{array}$ & 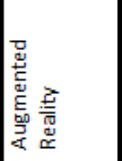 & ले & 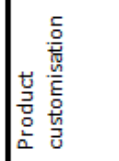 & 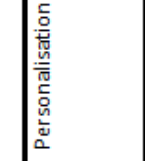 & 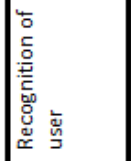 \\
\hline & 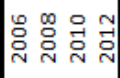 & 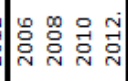 & 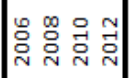 & 怘总 总 : & 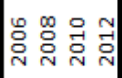 & 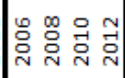 & : & 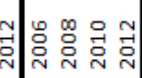 & 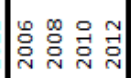 \\
\hline \multicolumn{10}{|l|}{ Burberry } \\
\hline \multicolumn{10}{|l|}{ Chanel } \\
\hline \multicolumn{10}{|l|}{ Chloé } \\
\hline \multicolumn{10}{|l|}{ Dior } \\
\hline \multicolumn{10}{|l|}{ Donna Karan } \\
\hline \multirow{2}{*}{\multicolumn{10}{|c|}{$\begin{array}{l}\text { Gucci } \\
\text { Hermes }\end{array}$}} \\
\hline & & & & & & & & & 1 \\
\hline \multicolumn{10}{|l|}{ Louis Vuitton } \\
\hline \multicolumn{10}{|l|}{ Marc Jacobs } \\
\hline \multicolumn{10}{|l|}{ Mulberry } \\
\hline \multirow{2}{*}{\multicolumn{10}{|c|}{$\begin{array}{l}\text { Paul Smith } \\
\text { Prada }\end{array}$}} \\
\hline & & & & & & & & 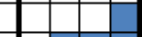 & 1 \\
\hline \multicolumn{10}{|l|}{ Ralph Lauren } \\
\hline $\begin{array}{l}\text { Valentino } \\
\end{array}$ & & & & & & & & - & -1 \\
\hline Versace & & & & & & & & & \\
\hline
\end{tabular}

